\title{
一般演題 6
}

\section{私の考案した胃切開鉏子について}

\section{北 原 哲 夫*}

近ごろ胃の手術にさいし，しばしば胃の内面 の観察の必要性が強調される.すなわち粘膜癌 や新鮮な胃潰瘍・糜爛などは，単に胃を外面か ら視診・触診しただけでは病変を容易に発見で きず，直接粘膜面を観察しなければこれを見落 とす可能性が大きい。このため開腹後，胃に小 切開を加えて内腔に捙入する手術中胃鏡とし て, 井口式 gastroviewer (胃手術用広角観察鏡) さえ考案されているほどである.もちろん広く 胃切開を施せば内腔の観察は容易であるが，実 際問題として胃切開を成書に記されたごとく行 なうのはとかくおっくうで，胃内容による腹膜

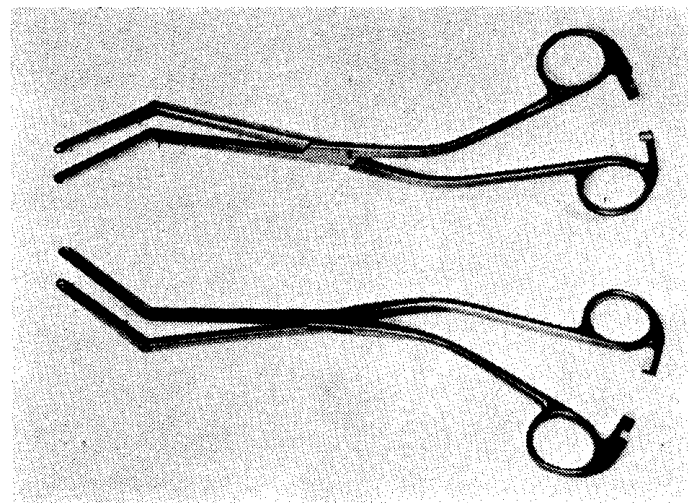

図 1 胃切開鏙子（関節を曲げた状贸）

腔污染のおそれもあり，胃切開創からの出血で 粘膜面の精密な観察が妨げられる傾向も少なく ない，私は胃切開を容易に，しかも出血なく行 なう目的で胃切開鉗子を考案した。

これは全長 $27 \mathrm{~cm}$ ，㣣把部 $12 \mathrm{~cm}$ ほどの長大 な 1 対の圧挫性鉗子であるが，鉗子の挾把部の 中央に関節があって，胃壁を挾んだまま 120 度 まで「く」の字形に屈曲せしめ得るのが特色で

*東京聥信病院外科
ある（図 1)、なお関節部より先端にかけては鉗 子の把持力を強めるため， 2 力所に $3 \mathrm{~mm}$ ほど の小突起をそなえている.

使用にさいしては，まず胃壁に鉗子の入るだ けの小切開を加え，ここから 1 対の鉗子を約 1 $\mathrm{cm}$ の間隔で並列するごとく挿入し，胃切開を 行なおうとする全長にわたって胃壁を挾む（図 2).ついで両鉗子の中間で直剪刀をもって胃壁

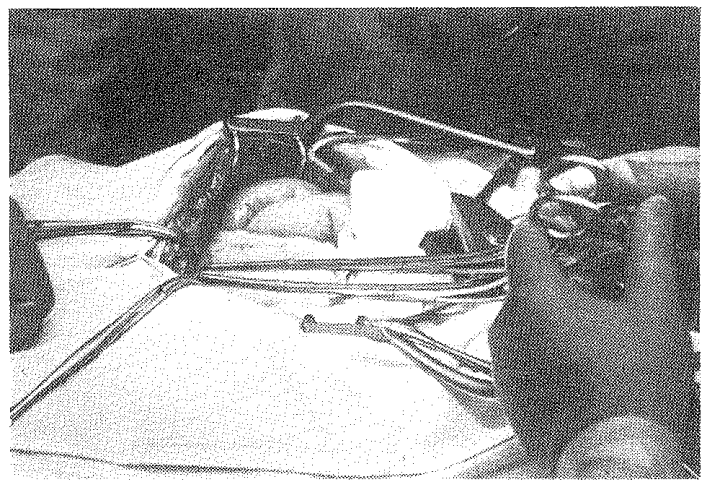

図 2 胃壁の小切開口より鉗子を挿 入，胃壁を挾把する

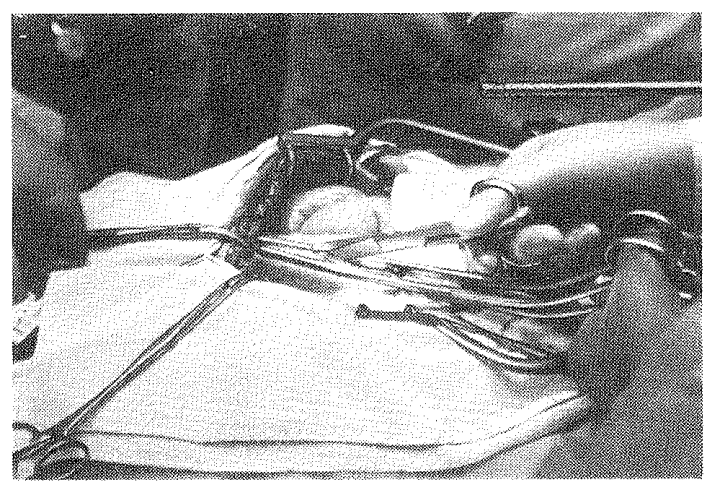

図 31 対の鉗子の中間で胃壁を切開する

を切開するが，出血は全くみられない（図 3). 切開を終わったら関節部で各鉗子を屈曲させれ ば胃切開口は菱形に広く開き，内腔の観察はも 


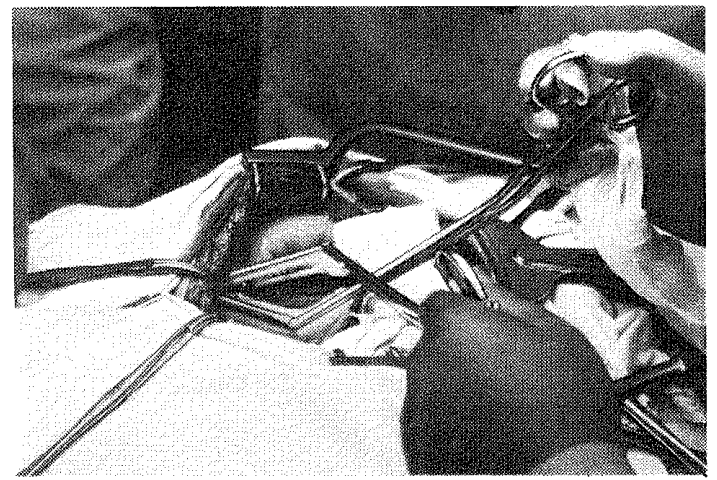

図 4 鋁子を屈曲させて胃切開口を広く開く

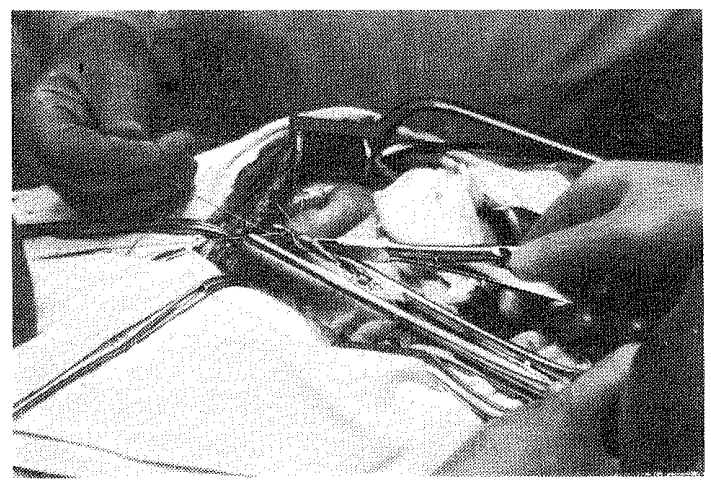

図 5 鉗子を再び並列させ，胃切開創の 閉鎖にかかる

とより，種々の胃内操作もすこぶる容易である

（図 4). 粘漠のヒダを腸べラなどで押し広げる ようにすれば，ヒダの間にある小病巣をも見逃 すおそれはない。

目的を果たしたら，鉗子の関節を伸展させて 再び両鉗子を並列せしめ，贯切開縁に接して全

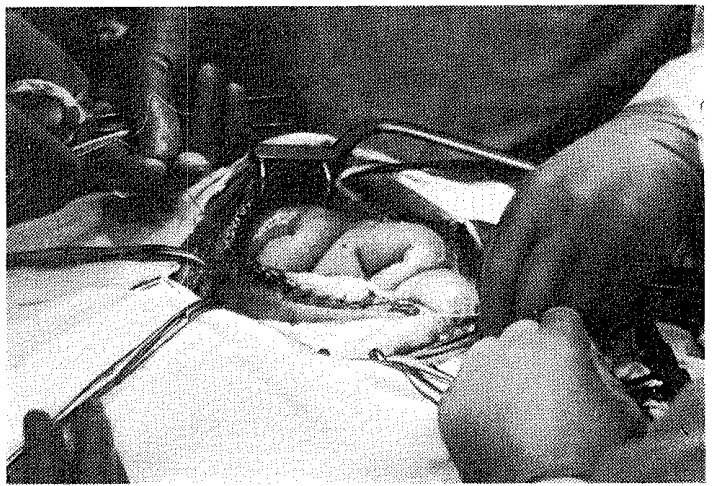

図 6 坄後に鉗子を抜去し，胃切䦕刢の 䋖合を完了する

層の連続縫合を施して胃の創を閉じ（図 5), 最 後の 1 針をかける直前に鉗子を抜去して絴合を 完了する (図 6). 胃切開創の出血点を個々に止 める必要はほとんどない.もし胃切開部を切除 しないなら，さらにその上に Lembert 縫合を 加えればよい，この胃切開鉗子を使えば，普通 の胃鉗子を用いなくても内容の漏洩をきたさ ず，腹膜腔の污染が確実に避けられ，田切開が 非常に安直に行なえるようになったのは大きな 利点である。

なお鉗子の長さや関節の角度等については, 目的によっていく種類かのものをそなえた方が 便利かとも思われ，目下さらに検討中である. 本試作に当って，泉工医科工業株式会社のご協 力を得たことを深く感謝する. 